\title{
Upaya Pemberdayaan Masyarakat Dalam Menciptakan Generasi Milenial Sadar Gizi Yang Bebas Stunting Melalui Kegiatan 1000 HPK
}

\author{
Nurul Hidayah ${ }^{1}$, Marwan $^{2}$ \\ 1,2 Akademi Keperawatan Pemerintah Kabupaten Ngawi, Indonesia \\ nurulridlo@gmail.com
}

\begin{abstract}
ABSTRAK
Stunting merupakan masalah gizi kronis yang disebabkan kurangnya asupan gizi dalam waktu lama, sehingga mengganggu pertumbuhan, perkembangan, kesehatan dan produktivitas anak. Salah satu upaya yang dilakukan pemerintah untuk menangani stunting dengan gerakan '1000 Hari Pertama Kehidupan'. Tujuan: pengabdian masyarakat ini adalah mengidentifikasi upaya pemberdayaan masyarakat dalam menciptakan generasi milenial sadar gizi yang bebas stunting melalui kegiatan 1000 HPK. Populasi target pada pengabdian masyarakat ini adalah warga Dusun Cung Belut yang memiliki anak balita sebanyak 40 orang, balita 40 orang, dan kader Posyandu sebanyak 10. Metode yang digunakan adalah pemberdayaan masyarakat melalui kegiatan pengukuran status gizi balita berdasarkan $\mathrm{PB} / \mathrm{U}$, penyuluhan dan pemberian makanan tambahan. Hasil dari pelaksanaan ini adalah dari pemeriksaan status gizi balita diketahui jumlah balita termasuk kategori normal sebesar 20 anak (50\%), kategori $80 \%$ ideal 4 anak $(10 \%)$, dan kategori pendek sebesar 16 anak (40\%). Dari kegiatan penyuluhan tentang pencegahan stunting diperoleh hasil tingkat pengetahuan audiens meningkat sebesar 78\%. Kesimpulan: kegiatan pemberdayaan masyarakat menggunakan metode penyuluhan efektif untuk mencegah stunting dan menciptakan generasi milenial sadar gizi.
\end{abstract}

Kata Kunci: Stunting Balita; 1000 HPK, Penyuluhan

\section{PENDAHULUAN}

Stunting masih menjadi masalah gizi kronis di Indonesia, sehingga melalui Program Rencana Pembangunan Jangka Menengah Nasional (RJPM) pemerintah menargetkan pada tahun 2025 akan mengurangi 40\% jumlah balita pendek. Untuk mencapai target tersebut pada tahun 2017 pemerintah Indonesia meluncurkan program penanggulangan stunting tingkat nasional dengan prioritas penanganan masalah gizi spesifik dan sensitif pada 1000 hari pertama kehidupan sampai dengan usia 6 tahun. Stunting disebabkan kurangnya asupan gizi dalam waktu cukup lama, sehingga mengakibatkan gangguan pertumbuhan pada anak yaitu ditandai dengan tinggi badan anak lebih rendah dari standar usianya. Dampak lain dari stunting adalah gangguan 
perkembangan, kesehatan, dan produktivitas, sehingga jika tidak ditangani akan menimbulkan masalah yang lebih besar, dan bangsa Indonesia dapat mengalami lost generation (Laili dan Andriani, 2019; Putri 2018; WHO, 2018).

Menurut World Health Organization (WHO) 2018 prevalensi balita stunting di dunia pada tahun 2017 sebesar 151 juta (22\%), Indonesia sendiri menempati posisi ketiga di kawasan Asia Tenggara sebesar (36,4\%). Hasil Riset Kesehatan Dasar Tahun 2018, prevalensi stunting di Indonesia mencapai 12.780 jiwa (42,6\%), sedangkan WHO memberikan batasan untuk stunting adalah $<20 \%$ (Kemenkes RI, 2018). Data dari Dinas Kesehatan Kabupaten Ngawi pada tahun 2019 prevalensi anak stunting di Ngawi sebesar 8.012 jiwa (Dinkes, 2019). Dari hasil wawancara dengan beberapa ibu-ibu yang memiliki balita di Dusun Cung Belut diketahui belum banyak terpapar mengenai stunting, sehingga beberapa dari mereka beranggapan bahwa anak lebih pendek dari usianya adalah faktor genetik sehingga tidak memerlukan penanganan lebih lanjut. Dusun Cung Belut, merupakan daerah dalam lingkup wilayah Puskesmas Teguhan. Sebagian besar bayi dan balita di dusun Cung Belut sudah mengikuti kegiatan posyandu, akan tetapi kesadaran dan pengetahuan masyarakat tentang stunting masih sangat rendah, hal ini dapat dilihat dari 70 balita di Dusun Cung Belut yang mengalami stunting.

Beberapa penyebab stunting adalah kurangnya asupan zat gizi yang diserap oleh tubuh sejak dalam kandungan sampai dengan setelah lahir, minimnya akses pelayanan kesehatan, akses air bersih dan sanitasi. Stunting juga dapat disebabkan oleh status gizi ibu saat hamil, riwayat panjang badan lahir pendek, riwayat Bayi Berat Lahir Rendah (BBLR), riwayat ASI, riwayat MPASI, tinggi badan ibu, jumlah keluarga, status ekonomi, tingkat pendidikan dan pekerjaan orangtua serta tidak lepas dari pola asuh (Kusuma, 2013; Nurkomala, 2017). Sehubungan dengan faktor-faktor penyebab stunting tersebut, pemerintah berupaya untuk menurunkan angka stunting diIndonesia melalui program gerakan 'Seribu Hari Pertama Kehidupan', yang mencakup upaya spesifik maupun sensitif. Upaya spesifik adalah kegiatan yang langsung berhubungan dengana masalah gizi seseorang, seperti pemberian suplementasi pada bayi dan balita, suplementasi Fe pada ibu hamil, pemberian makanan tambahan pada ibu hamil, pemenuhan gizi, persalinan dengan dokter atau bidan yang ahli, IMD (Inisiasi Menyusui Dini), ASI Eksklusif pada bayi sampai usia 6 bulan, pemberian makanan pendamping ASI mulai anak usia 6 bulan sampai dengan usia 2 tahun, berikan imunisasi dasar lengkap dan vitamin A, pantau pertumbuhan balita di posyandu terdekat, serta terapkan perilaku hidup bersih dan sehat. Akan tetapi pada kenyataannya Intervensi spesifik hanya mampu memberikan kontribusi $30 \%$ untuk masalah gizi stunting, sehingga untuk menuntaskan permasalahan stunting, penuntasanya yang70\% memerlukan keterlibatan lintas sektor (diluar sektor kesehatan) yang dikenal dengan intervensi sensitif (Kemenkes RI, 2012). Berdasarkan uraian diatas kegiatan pengabdian masyarakat ini ingin mengajak para orang tua dan kader posyandu untuk ikut berperan dalam pencegahan stunting dalam upaya menciptakan generasi milenia sadar gizi dan bebas stunting melalui kegiatan penyuluhan 1000 HPK.

Pengabdian masyarakat ini bertujuan mengidentifikasi upaya pemberdayaan masyarakat dalam menciptakan generasi milenial sadar gizi yang bebas stunting melalui kegiatan 1000 HPK.

\section{METODE}

Metode yang digunakan dalam kegiatan pemberdayaan masyarakat ini dengan melibatkan langsung masyarakat dalam setiap program melalui kegiatan Pemeriksaan antropometri balita, Penyuluhan, dan PMT 


\section{POPULASI}

Populasi dalam kegiatan ini adalah ibu-ibu yang mempunyai anak balita sebanyak 40 orang, balita 40 anak, dan kader posyandu balita 10 orang, yang tinggal di Dusun Cung Belut Desa semen

\section{WAKTU PELAKSANAAN}

Pengabdian masyarakat ini dilakukan pada Bulan Februari-Maret 2020

\section{HASIL DAN PEMBAHASAN \\ Data demografi}

Jumlah penduduk dusun Gebangsewu pada tahun 2018 adalah: 675 jiwa, dengan penduduk laki-laki sebesar 334 jiwa, perempuan 341 jiwa. Distribusi penduduk berdasarkan kelompok usia: Balita 35 orang, Anak 69 orang, Remaja 96 orang, Dewasa 347 orang, dan Lansia 128 orang. Terdapat 249 KK dan 217 soma.

\section{Pekerjaan Dan Pendapatan}

Sebagian warga bekerja sebagai petani sebanyak 217 orang, Wiraswasta 142, IRT 93, Karyawan swasta 12, Pedagang 12, TNI 1, PNS 7, Buruh tani 12, Pensiun 1, Pengangguran 12, belum usia bekerja 166 orang, dengan pendapatan rata-rata $\mathrm{Rp} 1.000 .000-\mathrm{Rp} 2.000 .000$

\section{Kegiatan Pemeriksaan status gizi balita}

Pada kegiatan pengabdian masyarakat ini dilakukan pemeriksaan status gizi balita , meliputi pengukuran BB/U, TB/U. pemeriksaan ini dilakukan sesaat setelah audiens datang. Dari 40 balita yang hadir dapat disimpulkan hasil pemeriksaannya status gizi $\mathrm{PB} / \mathrm{U} 20$ anak kategori normal, 4 anak kategori 80\% ideal, dan 16 anak kategori pendek.

\section{Kegiatan Penyuluhan tentang cegah stunting sejak 1000 hari pertama kehidupan dan} dilanjutkan dengan gizi seimbang diusia Balita.

Kegiatan penguluhan ini ditujukan meningkakan pengetahuan warga tentang pentingnya mencegah stunting sejak 1000 hari pertama kehidupan dan dilanjutkan dengan gizi seimbang di usia Balita. Kegiatan ini dilaksanakan menjadi beberapa tahap, antara lain persiapan, pelasanaan dan evaluasi. Tahap persiapan meliputi kegiatan koordinasi dengan perangkat Desa seperti Kades, Kasun, Ketua RT/RW dan kader untuk mensosialisasikan rencana kegiatan penyuluhan yang akan dilakukan pada tanggal 11 Februari 2020. Tema dari penyuluhan ini adalah "Cegah stunting sejak 1000 hari pertama kehidupan dan dilanjutkan dengan gizi seimbang diusia Balita ". Masyarakat yang menjadi target sasaran penyuluhan adalah ibu-ibu yang mempunyai balita, para balita dan para kader Posyandu Balita yang tinggal di Dusun Cung Belut sejumlah 100 orang. Pada tahap pelaksanaan kegiaatan dilakukan dengan cara merealisasikan rencana penyuluhan pada tanggal 11 Februari 2020 yang bertempat di rumah salah satu warga Dusun Cung belut yaitu bpk Tekad. Pada kegiatan ini kami mendapatkan dukungan penuh dari perangkat Desa dan warga, hal ini dapat dilihat dari persiapan sampai pelaksanaan kegiatan yang kami lakukan. Warga membantu menyiapkan tempat, tikar, peralatan perlengkapan penyuluhan seperti sound, dan LCD dari kantor Desa. Dukungan lain dari warga juga diperlihatkan dengan warga datang terlebih dahulu sebelum acara dimulai. Antusiasme warga juga sangat tinggi, hal ini dilihat dari banyaknya pertanyaan yang diungkapkan saat penyuluhan berlangsung. Pada pelaksanaan kegiatan ini kami menggunakan metode ceramah, diskusi dan pemutaran video, tentang Stunting dan dampaknya bagi generasi masa depan. Pada tahap ini juga dilakukan kegiatan pre dan post test tentang pengetahuan audien seputar stunting dengan menggunakan quesioner. Item pertanyaan seputar pengertian balita pendek, penyebab, tanda dan gejala, dampak yang dimunculkan dari stunting dan cara pencegahan stunting. 
Evaluasi dilakukan dengan memberikan kuesioner yang sama seperti saat sebelum diberikan penyuluhan. Hasil evaluasi dari kegiatan ini diperoleh hasil pemahaman audiens tentang stunting dan cara mencegahnya meningkat sebesar $75 \%$. Hal ini dapat dilihat dari jumlah soal yang dapat dijawab dengan benar oleh audiens tentang Stunting. Pemberdayaan masyarakat melalui metode penyuluhan menggunakan audio visual terbukti efektif untuk meningkatkan pemahaman masyarakat tentang suatu penyakit, hal ini sesuai dengan penelitian Dianna, dkk (2020) yang mengatakan bahwa Media video lebih efektif terhadap peningkatan pengetahuan ibu balita tentang stunting di Puskesmas Pontianak Saigon Kecamatan Pontianak Timur.

\section{Kegiatan Penyuluhan tentang pentingnya pemeriksaan saat kehamilan}

Pada kegiatan pengabdian masyarakat ini juga diberikan penyuluhan kesehatan tentang pentingnya pemeriksaan kesehamilan untuk mencegah stunting dimasyarakat. Hal ini sesuai dengan upaya pemerintah dalam pencegahan stunting di Indonesia dengan menggulirkan program $1000 \mathrm{HPK}$. Dalam program tersebut terdapat upaya kesehatan spesifik salah satunya dengan memotivasi ibu hamil untuk rutin melakukan pemeriksaan kesehatan minimal 4 kali selama kehamilan, Pemberian makanan tambahan bagi ibu hamil dari kelompok miskin dan Suplementasi tablet tambah darah (Satriawan, 2018)

\section{Pemberian contoh menu seimbang dan PMT pada balita.}

Salah satu solusi dalam penanganan stunting pada balita adalah dengan melakukan Pemberian Makanan Tambahan (PMT) (Permenkes Republik Indonesia Nomor 51 Tahun 2016). Prevalensi balita 6-59 bulan di Indonesia yang mendapat Pemberian Makanan Tambahan (PMT) tahun 2018 sebesar 41\%. Pemberian Makanan Tambahan (PMT) adalah upaya memberikan makanan tambahan berbasis pangan lokal dengan resep-resep yang dianjurkan. Makanan lokal lebih bervariasi namun metode dan lamanya memasak sangat menentukan ketersediaan zat gizi yang terkandung didalamnya (Permenkes Republik Indonesia No 51 Tahun 2016). Suplementasi gizi dapat juga diberikan berupa makanan tambahan pabrikan, yang lebih praktis dan lebih terjamin komposisi zat gizinya. Pemberian makanan tambahan yang ditujukan untuk kelompok rawan meliputi balita 6-24 bulan dengan kategori kurus yaitu balita dengan hasil pengukuran berat badan menurut panjang badan $(\mathrm{BB} / \mathrm{PB})$ lebih kecil dari minus dua Standar Deviasi (-2 SD), anak usia sekolah dasar dengan kategori kurus, dan ibu hamil kurang energi kronis yaitu ibu hamil dengan hasil pengukuran Lingkar Lengan Atas (LiLA) lebih kecil dari 23,5 cm (Permenkes,RI, 2016). Lama pemberian idealnya 180 hari (2 hari sekali). Tambahan makanan untuk menambah asupan gizi untuk mencukupi kebutuhan gizi agar tercapainya status gizi yang baik (Permenkes Republik Indonesia Nomor 51 Tahun 2016). Makanan tambahan yang diberikan dapat berbentuk makanan keluarga. Pada pengabdian masyarakat ini pemberian PMT dilakukan pada semua kelompok balita yang hadir dalam bentuk makanan keluarga. Hal ini sesuai dengan penelitian Waroh (2019) yang mengatakan bahwa Pemberian makanan tambahan dapat menurunkan angka kejadian stunting.

\section{KESIMPULAN}

Pemberdayaan masyarakat dalam menciptakan generasi milenial sadar gizi yang bebas stunting melalui kegiatan 1000 HPK dengan menggunakan metode penyuluhan, dan pemberian PMT terbukti efektif untuk meningkatkan pemahaman warga tentang stunting dimasyarakat. 


\section{SARAN}

Diharapkan metode pemberdayaan masyarakat ini dapat diduplikasi untuk pengentasan masalah-masalah stunting dimasyarakat

\section{DAFTAR PUSTAKA}

Adriani, M. and Wijratmadi, B. (2014). Gizi dan Kesehatan Balita peranan makro zinc pada pertumbuhan balita. Jakarta : Prenamedia Group.

Ainun, S. (2019). Gambaran Tinggi Badan Ibu Dan Bbl ( Berat Badan Lahir ) Anak Dengan Kejadian Stunting di Sd Negeri 054901 Sidomulyo Stabat Kabupaten Langkat. Karya Tulis Ilmiah. D III Gizi, Politkenik Kesehatan Meda Jurusan Gizi. Medan. Available at:http://repo.poltekkesmedan.ac.id/xmlui/handle/123456789/1557. Diakses pada tanggal 23-12-19 pukul 23:41WIB.

Arisman.2004.Gizi dalam Daur Kehidupan: Buku Ajar IlmuGizi. Buku Kedokteran Jakarta: EGC.

ASEAN, UNICEF and WHO. Regional Report On Nutrition Security In Asean 2. Bangkok. UNICEF. 2016 tersedia dalam: .https://www.unicef.org/eapro/Regional Report on Nutrition_Security in

Aulia, D. (2016). Determinan stunting pada anak usia 24-59 bulan di kelurahan cimahpar, kecamatan bogor utara.skripsi Fakultas Ekologi Manusia, Institut Pertanian Bogor. Bogor. Available at: https://repository.ipb.ac.id/handle/123456789/86742. Diakses pada tanggal 15-11-19 pukul 16:48 WIB.

BAPPENAS RI.2012.Pedoman Perencanaan Program GerakanSadar Gizi dalam Rangka Seribu Hari PertamaKehidupan (1000 HPK), hal:1-8.

Dalimunthe, S. M. (2015). Gambaran Faktor-Faktor Kejadian Stunting Pada Balita Usia 24-59 Bulan Di Provinsi Nusa Tenggara Barat Tahun 2010 ( Analisis Data Sekunder Riskesdas 2010 ).skiprsi. Fakultas Kedokteran dan Ilmu Kesehatan, Universitas Islam Negeri Syarif Hidayatullah. Jakarta. Available at: http://repository.uinjkt.ac.id/dspace/handle/123456789/37993. Diakses pada tanggal 21-11-19 pukul 10:06 WIB

Dewey,K.G., Mayers,D.R. 2011. Early child growth: how donutrition and infection interact?. Blackwell PublishingLtd. Maternal and Child Nutrition (2011),7 (Suppl.3),pp.129-142 http: // onlinelibrary. wiley. com / journal.

Dianna., Septianingsih, N., Pangestu. J.F, 2020. Perbedaan pengetahuan ibu balita sebelum dan sesudah diberikan penyuluhan tentang stunting melalui media video dan leaflet di wilayah kerja puskesmas saigon kecamatan pontianak timur, Jurnal Kebidanan Khatulistiwa, 6(1), Tersedia dalam http://ejournal.poltekkes-pontianak.ac.id/index.php/JKK/article/view/493

Fadlun and Feryanto, A.(2012). Asuhan Kebidanan Patologis. Jakarta : Salemba Medika.

Hardinsyah and Supriasa, I. D. N.(2016). Ilmu Gizi Teori \& Aplikasi. Jakarta : EGC.

Illahi, R. K. (2017). Hubungan Pendapatan Keluarga, Berat Lahir, Dan Panjang Lahir 


\section{Journal of Community Engagement in Health}

http://jceh.org

ISSN: 2620-3758 (print); 2620-3766 (online)

https://doi.org/10.30994/jceh.v3i1.41

Vol.3 No.1. March 2020. Page.86-93

Dengan Kejadian Stunting Balita 24-59 Bulan Di Bangkalan, Jurnal Manajemen Kesehatan. 3(1), pp. 1-14. Available at: http://jurnal.stikesyrsds.ac.id/index.php/JMK/article/view/85. Diakses pada tanggal 13-11-19 pukul 16:04 WIB.

Joyce C, Goodman-Bryan M, Hardin A.2016.Preterm Birthand Low Birth Weight

Juliani, U. (2018). Hubungan Pola Asuh Orang Tua Dengan Kejadian Stunting Pada Balita

Di Paud Al Fitrah Kecamatan Sei Rampah Kabupaten Serdang Bedagai Tahun 2018. skripsi. D IV Kebidanan, Politeknik Kesehatan Kemenkes RI Medan. Medan. Available at: http://ecampus.poltekkes-medan.ac.id/jspui/handle/123456789/834. Diakses pada tanggal 25-12-19 pukul 14:30 WIB

Kartini . (2018). Hubungan Anemia Dalam Kehamilan Dengan Panjang Badan Bayi Baru Lahir Di Rumah Sakit Benyamin Guluh Kabupaten Kolaka Tahun 2018, Health Information : Jurnal Penelitian. 10(1), pp. 33-38. doi: https://doi.org/10.36990/hijp.v10i1.101. Diakses pada tanggal 21-12-19 pukul 12:05 WIB.

Kemenkes RI. (2011). Standar Antoropometri Penilaian Status Gizi Anak,.P. 8,27.

Kementerian Kesehatan,RI.2014. Pedoman gizi seimbang,Jakarta.

Kementerian Kesehatan Republik Indonesia. Kualitas manusiaditentukan pada 1000 hari pertama kehidupannya.Artikel publikasi, 2017.www.kemenkes.go.id

Kementerian Desa, pembangunan D. T. dan T.(2017). Buku Saku Desa dalam Penanganan stunting.

Kementerian Kesejahteraan Rakyat RI \& Badan Perencanaan Pembangunan Nasional. Kerangka Kebijakan Gerakan 1000 Hari Pertama Kehidupan. Kemenkokesra: Jakarta; 2013

Kementerian bidang Kesejahteraan Rakyat, 2013.Pedomanperencanaan program Gerakan Nasional percepatanperbaikan gizi dalam rangka seribu hari pertamakehidupan (Gerakan 1000 HPK), Jakarta.

Laili, U., dan Andriani. R.A.D. (2019). Pemberdayaan Masyarakat Dalam Pencegahan Stunting, Jurnal Pengabdian Masyarakat Ipteks 5(1) Juni

Mokodimpit, E. P., Kapantow, N. H. And Mayulu, N. (2018) . Hubungan Antara Tinggi Badan Orang Tua Dengan Kejadian Stunting Pada Anak Usia 24-59 Bulan Di Wilayah Kerja Puskesmas Pusomaen Kabupaten Minahasa Tenggara, Jurnal Kesmas. 7(5), Pp. 4-5. Available at: https://ejournal.unsrat.ac.id/index.php/kesmas/article/view/22421. Diakses pada tanggal 10-12-19 pukul 05:58 WIB.

Nurkomala, S. (2017). Praktik Pemberian Mpasi (Makanan Pendamping Air Susu Ibu) Pada Anak Stunting Dan Tidak Stunting Usia 6-24 Bulan'. Skripsi. Fakultas Kedokteran, Universitas Diponegoro. Semarang. doi: 10.14710/jnc.v7i2.20822. diakses pada tanggal 29-11-19 pukul 14:26 WIB.

Oktarina,Z.

and Sudiarti,

T.

2013). Faktor Risiko Stunting Pada Balita (24-59 Bulan) Di Sumatera, Jurnal

Gizi dan Pangan. 8(3), pp. 175-180. doi: 


\section{Journal of Community Engagement in Health}

http://jceh.org

ISSN: 2620-3758 (print); 2620-3766 (online)

https://doi.org/10.30994/jceh.v3i1.41

Vol.3 No.1. March 2020. Page.86-93

http://dx.doi.org/10.25182/jgp.2013.8.3.177-180. Diakses pada tanggal 21-12-19 pukul 18:43 WIB.

Peraturan Menteri Kesehatan Republik Indonesia Nomor 51 Tahun 2016, Standar Produk Suplementasi Gizi, Lembaran Negara Republik Indonesia Tahun 2016 Nomor 1600, Jakarta

Pudjiadi,S.2005.Ilmu Gizi Klinis Pada Anak. Edisi Keempat FKUI

Putri, T. A.( 2018). Faktor Risiko Kejadian Stunting Pada Balita Kotagede I Kota Yogyakarta Tahun 2018 Faktor Risiko Kejadian Stunting Pada Balita Usia 25-59 Bulan Di Wilayah Puskesmas Kotagede I Kota Yogyakarta. Skripsi. Sarjana Terapan Kebidanan,Politeknik Kesehatan Kementerian Kesehatan Yogyakarta. Yogyakarta. Available at: http://eprints.poltekkesjogja.ac.id/1712/. Diakses pada tanggal 09-12-19 pukul 18:23 WIB.

Ramayulis, R.dkk. (2018). Stop Stunting dengan Konseling Gizi. Jakarta : Swadaya Group.

Ratu, N. C., Punuh, M. I. and Malonda, N. S. H. (2018). Hubungan Tinggi Badan Orangtua Dengan Kejadian Stunting Pada Anak Usia 24-59 Bulan Di Kecamatan Ratahan Kabupaten Minahasa Tenggara, Jurnal KESMAS, 7(4), pp. 2-8. Available at: https://ejournal.unsrat.ac.id/index.php/kesmas/article/view/23155. Diakses pada tanggal 21-11-19 pukul 15:50 WIB.

Rosha,B.C dkk, 2016. Rosha BC, Sari K, SP Indri Y, Amaliah N,Utami NH. Peran intervensi gizi spesifik dan sensitive dalam perbaikan masalah gizi balita Kota Bogor. BuletinPenelitian Kesehatan. Vol.44 (2); 127-138

Sandjaja.2009.Risiko Kekurangan Energi Kronis (KEK) padalbuHamil di Indonesia. Gizi Indonesia. Vol.32(2): 128-38.

Sastria, A., Hasnah and Fadli. (2019). Faktor Kejadian Stunting Pada Anak Dan Balita, Jurnal Ilmiah Keperawatan Ilmiah Hang Tuah Surabaya, 14(2), pp. 105-106. Available at: http://journal.stikeshangtuahsby.ac.id/index.php/JIKSHT/article/view/56. Diakses pada tanggal 12-12-19 pukul 14:31 WIB.

$\begin{array}{lllll}\text { Satriawan, } & \text { E. } & \text { (2018). } & \text { Strategi } & \text { Nasional }\end{array}$ Percepatan Pencegahan Stunting 2018-2024. Tim Nasional Percepatan Penanggulangan Kemiskinan (TNP2K)

Sekretariat Wakil Presiden Republik Indonesia

Septikasari, M. (2018). Gizi Anak Dan Faktor Yang Mempengaruhinya. Yogyakarta : UNY press.

Sholecha, R. P. (2018). Analisis Faktor Yang Berhubungan Dengan Pencegahan Stunting Pada Anak Usia 2-5 Tahun Berdasarkan Teori Health Promotion Model (Hpm). Skripsi.s1 Keperawatan. Fakultas Kesehatan. Universitas Airlangga, Surabaya. Available at: http://repository.unair.ac.id/82064. Diakses pada tanggal 17-11-19 pukul 13:46 WIB. 
Sostinengari, Y. (2018). Analisis Data Hasil Pemantauan Status Gizi “ Faktor Determinan Kejadian Stunting Pada Balita Usia 6 - 59 Bulan Di Kabupaten Konawe Kepulauan Pada Tahun 2016.Skripsi.Diploma IV gizi. Politeknik Kesehatan Kendari, Kendari. Available at: http://repository.poltekkes-kdi.ac.id/752/. Diakses pada tanggal 2212-19 pukul 15:41 WIB.

Sukarni, I. And Wahyu. (2013). Buku Ajar Keperawatan Maternitas.Yogyakarta : Nuha Medika

Swathma, D., Lestari, H. and Ardiansyah, R. T. (2016). Riwayat Imunisasi Dasar Terhadap Kejadian Stunting Pada Balita Usia 12-36 Bulan Di Wilayah Kerja Puskesmas Kandai Kota Kendari, pp. 1-10. Available at: http://ojs.uho.ac.id/index.php/JIMKESMAS/article/view/1088. Diakses pada tanggal 02-12-19 pukul 14:50 WIB.

The Lancet. Maternal and Child Nutrition: Executive Summaryof the Lancet Maternal and Child Nutrition Series. TheLancet; 2013. 1-12

Tim Nasional Percepatan Penanggulangan Kemiskinan .100 Kabupaten/Kota Prioritas Untuk Intervensi Anak Kerdil (Stunting). JakartaPusat. Sekretariat Wakil Presiden Indonesia. 2017

UKAID. Scalling Up Nutrition: The UK's position paper onundernutrition. Departement of InternationalDevelopment, September 2011.

USAID.2014.Multi-sectoral Nutrition Strategy 2014-2025Technical Guidance Brief: Implementation Guidance forEnding Preventable Maternal and Child Death.Hal1-6

Waroh, Y.K., 2019. Pemberian makanan tambahan sebagai upaya penanganan stunting pada balita di indonesia, Embrio Jurnal kebidanan vol 11 No 1, tersedia dalam: http://jurnal.unipasby.ac.id/index.php/embrio/article/view/1852

World Health Organization (WHO).(2018). World Health Statistic.

Winasis, N. P. (2018). Analisis Faktor Kejadian Stunting Pada Anak Usia 24-59 Bulan Berbasis Transcultural Nursing Di Desa Morombuh Kecamatan Kwanyar Bangkalan. skripsi. Fakultas Keperawatan, Universitas Airlangga. Available at: http://repository.unair.ac.id/85288/. Diakses pada tanggal 25-12-19 pukul 20:08 WIB.

Yusdarif. (2017). Determinan Kejadian Stunting Pada Balita Usia 24-59 Bulan Di Kelurahan Rangas Kecamatan Banggae Kabupaten Majene Tahun 2017. skripsi. Fakultas Kedokteran dan Ilmu Kesehatan, UIN Allauddin. Makasar. Available at: http://repositori.uin-alauddin.ac.id/8113/. Diakses pada tanggal 22-12-19 pukul 07:53 WIB. 